\title{
Effect of a Probiotic Lactobacillus plantarum CR1T5 Dietary Supplements on Non-specific Immunity in Black Eared Catfish (Pangasius larnaudii)
}

\section{Somrudee Silarudee ${ }^{1}$, Saowanit Tongpim², Nicha Charoensri ${ }^{3}$ and Sompong Doolgindachbaporn ${ }^{1 *}$}

${ }^{1}$ Department of Fisheries, Faculty of Agriculture, Khon Kaen University, Thailand. ${ }^{2}$ Department of Microbiology, Faculty of Science, Khon Kaen University, Thailand. ${ }^{3}$ Department of Clinical Microbiology, Faculty of Associated Medical Sciences, Khon Kaen University, Thailand.

\begin{abstract}
The effects of a probiotic Lactobacillus plantarum CR1T5, at various concentrations $\left(0,10^{6}, 10^{7}, 10^{8}\right.$ and $10^{9} \mathrm{cfu}^{-1}$ ) in dietary supplements for Black Eared Catfish (Pangasius larnaudii) were investigated. Fish were randomly allocated into 5 treatments with 3 replications and reared for 60 days. The growth performance, non-specific immunity and disease resistance were determined at 15, 30, 45 and 60 days. The results revealed that at day 15 the fish received probiotic dietary supplements at $10^{7}, 10^{8}$ and $10^{9} \mathrm{cfu}^{-1}$ had significantly higher Specific growth rate (SGR) and lower feed conversion ratio (FCR) than the fish received control diet. On the other hand, fish fed $10^{6} \mathrm{cfu} \mathrm{g}^{-1}$ dietary supplement had significantly higher SGR and lower FCR at day 45. For immune parameters, the respiratory burst activity was significantly increased after 30 days. Probiotic diets at $10^{8}$ and $10^{9} \mathrm{cfu} \mathrm{g}^{-1}$ significantly improved complement activity after $\mathbf{1 5}$ days and significantly enhanced lysozyme activity after $\mathbf{4 5}$ days of feeding. All fish received probiotic dietary supplement displayed a significantly increased survival rate post-challenge with $A$. hydrophila. This study found that the optimum probiotic dietary supplement at $10^{8} \mathrm{cfu}^{-1}$ had significantly improved growth performance, immune stimulation and disease resistance in $P$. larnaudii.
\end{abstract}

Keywords: Black Eared Catfish, Lactobacillus plantarum, Pangasius larnaudii, non-specific immunity, probiotic.

\footnotetext{
*Correspondence: sompng_d@kku.ac.th

(Received: 28 December 2018; accepted: 02 February 2019)
}

Citation: Somrudee Silarudee, Saowanit Tongpim, Nicha Charoensri and Sompong Doolgindachbaporn, Effect of a Probiotic Lactobacillus plantarum CR1T5 Dietary Supplements on Non-specific Immunity in Black Eared Catfish (Pangasius larnaudii), J Pure Appl Microbiol., 2019; 13(1):289-296 doi: 10.22207/JPAM.13.1.31

(C) The Author(s) 2019. Open Access. This article is distributed under the terms of the Creative Commons Attribution 4.0 International License which permits unrestricted use, sharing, distribution, and reproduction in any medium, provided you give appropriate credit to the original author(s) and the source, provide a link to the Creative Commons license, and indicate if changes were made. 


\section{INTRODUCTION}

Black Eared Catfish (Pangasius larnaudii) is a large freshwater fish species in genus Pangasius which has been found in large rivers of the Chao Phraya and Mekong basins (Rainboth, 1996) ${ }^{1}$. P. larnaudii has an important value in the markets as ornamental fish. The propagation of this fish can now be successful, however, there are many problems which lead to low survival rate. One of the major problems is infectious disease. The farmers usually use antibiotics and chemicals for disease prevention and control. Using antimicrobial drugs and chemical compounds not only increase production cost, but the longterm uses of antimicrobial drugs also has cause the evolution of resistant strains of bacteria. It is important to develop the alternative method, like probiotic bacteria, to solve this problem. Probiotic is the bacteria associated with beneficial effects to humans and animals. It is used as biological control agents of disease in aquaculture to replace conventional drugs and reduce the use of antibiotics, Probiotics are microorganisms which generally recognized as safe (GRAS) (Brien et al., $1999)^{2}$ to human and animal including aquatic animal.

Lactobacillus is one of the most important lactic acid bacteria. It is characterized as gram positive, rod sharp, non-motile and non-spore forming that produce lactic acid as a major product of fermentative metabolism (Ringo and Gatesoupe, 1998) $)^{3}$. Lactobacillus has been used as probiotic in aquaculture. It improves production and enhances immune system especially the non-specific or innate immune response in fish. The primary line of defense in fish is the skin and mucus membranes. However, when pathogenic microorganisms enter the fish, cellular and humoral innate defense mechanisms are activated. At present, there are few reports on the effects of Lactobacillus, particularly Lactobacillus plantarum on lysozyme activity, respiratory burst activity and complement activity which have been frequently used as indicators of nonspecific immune functions. The increases in these activities improve health performance of fish by controlling pathogens (Verschuere et al., 2000) ${ }^{4}$

The aims of this study were to determine the effects of Lactobacillus plantarum CR1T5 dietary supplements on non-specific immunity and to investigate the optimal concentration of $L$. plantarum CR1T5 on growth performance, nonspecific immunity and survival rate in $P$. larnaudii.

\section{MATERIALS AND METHODS}

\section{Preparation of Experimental Diets and Probiotic Supplementation}

In this study, commercial pelleted feed containing at least $30 \%$ protein was used as a basal diet. Probiotic culture of L. plantarum CR1T5 prepared following Meidong et al. (2017) was obtained from Department of Microbiology, Faculty of Science, Khon Kaen University, Thailand. Cell suspension of $L$. plantarum $C R 1 T 5$ was mixed with basal diet at $0,10^{6}, 10^{7}, 10^{8}$ and $10^{9} \mathrm{cfu} \mathrm{ml}^{-}$ 1 , air dried and kept in sealed containers at $4^{\circ} \mathrm{C}$ for immediate uses. These feed mixtures were prepared daily.

Preparation of Experimental Fish (Black Eared Catfish, Pangasius larnaudii)

Two weeks prior to the experiments, black eared catfishes were maintained in 1000 litre tanks and acquired to feed on a basal diet twice a day. Fishes with weight ranging between $82.84 \pm 3.35 \mathrm{~g}$ were allocated in a completely randomized design (CRD). Fifteen aquaria with 150 $L$ capacity were used as experimental unit. Each aquarium contained 10 fish. Five levels of probiotic mixture i.e. $0,10^{6}, 10^{7}, 10^{8}$ and $10^{9} \mathrm{cfu} \mathrm{g}^{-1}$ with 3 replications were assigned. During the experiment, water quality was maintained (temperature, $\mathrm{pH}$ and DO were $26.8-27.8^{\circ} \mathrm{C}, 6.6-7.5$ and $6.0-7.0 \mathrm{mg}$ $\mathrm{I}^{-1}$, respectively) within the acceptable range for aquaculture (Stickney, 2009) ${ }^{6}$.

\section{Sample Collection}

Data were collected at 15, 30, 45 and 60 day intervals. One day prior to the data collection, experimented fish were abstained from feeding. Fish were anaesthetized with MS-222. Two individuals from each replicate were randomly taken for measuring growth performance and feed efficiency. For Blood sampling, a 26G-syringe and ordinary 1-ml plastic syringe were administered to draw blood through caudal vein.

For lysozyme and complement activities, another $0.5 \mathrm{ml}$ blood sample was drawn with uncoated syringe, then transferred to microcentrifugal tube and sit for $1 \mathrm{hr}$ at room temperature and at $4^{\circ} \mathrm{C}$ for solidification. Serum was extracted using centrifuge at $3000 \mathrm{rpm}$ for 5 
mins and kept at $-20^{\circ} \mathrm{C}$. For nitrobluetetrazolium reduction activities, $1 \mathrm{ml}$ of blood sample was drawn with hypodermic needle coated with heparin and transferred to a conical tube already containing $3 \mathrm{ml}$ of Roswell Park Memorial Institute Medium (RPMI 1640). Samples were kept ice cold for lymphotic leucocyte extraction by centrifugal technique.

\section{Non-specific Immunoassay Lysozyme activity assay}

Lysozyme activity assay explained by Obach et al.(1993). ${ }^{7}$ was followed. Twenty-five $\mathrm{ml}$ of serum from Black Eared Catfish was placed in a well-plate, 3 wells per sample followed by addition of $0.02 \%$ Micrococcusly sodeikticusin $175 \mathrm{ml}$ of $0.05 \mathrm{M}$ PBS, pH 6.2. Kinetic mode was measured every 0.5 min-interval for 5 mins at $530 \mathrm{~nm}$. Lysozyme concentration obtained was later compared against standard concentration of hen egg white lysozyme (HEWL) and reported as milligram per milliliter $\left(\mathrm{mg} \mathrm{ml}^{-1}\right)$.

\section{Respiratory burst activity}

An assay of respiratory burst activity explained by Secombes $(1990)^{8}$ was followed with a slight modification. Prepared $175 \mathrm{ml}$ leucocyte

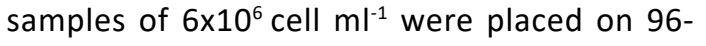
well plate, topped with $25 \mathrm{ml} \mathrm{NBT}$ each well and incubated at room temperature for 2 hrs. Clear supernatant was discarded, remaining solution was then carefully washed with $125 \mathrm{ml}$ absolute methanol twice and air-dried. $125 \mathrm{ml}$ of $2 \mathrm{~N} \mathrm{KOH}$ followed by $150 \mathrm{ml}$ of DMSO were later added. The respiratory burst activity was expressed as $\mathrm{A} 655$ $\mathrm{nm}$. Spontaneous $\mathrm{O}_{2}^{-}$Production $=($Absorbance NBT reduction of sample - Absorbance of blank) Alternative complement

Method of complement activity study by Yano $(1992)^{9}$ was modified. Three $\mathrm{ml}$ of rabbit red blood cell ( $R$ RRBC) was prepared in a $15 \mathrm{ml}$ conical tube and centrifuged at $2500 \mathrm{rpm}$ for 5 mins. Clear supernatant was discarded. Remaining RaRBC was washed twice with PBS and spun at $2500 \mathrm{rpm}$ for 5 mins and finally washed three times with EGTA-mg GVB at 2500 rpm for 5 mins at room temperature. Final RaRBC concentration was made up to $2 \times 10^{8}$ cell $\mathrm{ml}^{-1}$ with EGTA-mg GVB.

Fish serum was diluted 20 folds from 50 $\mathrm{ml}$ serum in $0.01 \mathrm{M} \mathrm{EGTA-mg} \mathrm{GVB} 450 \mathrm{ml}$ to given ratios of 1:20,1:40, 1:80, 1:160 and 1:320. Conical tube containing only $0.01 \mathrm{M}$ EGTA-mg GVB $20 \mathrm{ml}$ and another containing $100 \%$ cell lysis in $3.4 \mathrm{ml}$ deionized distilled water were used as control. Every conical tube was added with $100 \mathrm{ml} \mathrm{RaRBC}$, incubated at $20^{\circ} \mathrm{C}$ for 90 mins, shaken every $15-$ 20 mins, followed by addition of $3.15 \mathrm{ml}$ of $85 \%$ $\mathrm{NaCl}$ and lastly centrifuged at $2500 \mathrm{rpm}, 4^{\circ} \mathrm{C}$ for 5 mins. OD was measured at $414 \mathrm{~nm}$. Complement activities was expressed as $\mathrm{ACH} 50{\text { unit' } \mathrm{ml}^{-1}}^{-1}$

$\mathrm{ACH} 50$ value $\left(\right.$ unit $\left.\mathrm{ml}^{-1}\right)=1 / \mathrm{k} \times$ (reciprocal of the serum dilution) $\times 0.5$

Where $\mathrm{K}$ is the amount of serum giving 50 $\%$ hemolysis, 0.5 is the correction factor since this assay was performed on half scale of the original method.

\section{Challenge test}

After 60 days of probiotic diet supplementation, ten individuals Black Eared Catfish was randomly selected and injected with $0.1 \mathrm{ml}$ of Aeromonas hydrophila FW52, ( $\sim 10^{7} \mathrm{cfu}$ $\mathrm{ml}^{-1}$ ) into abdominal cavity (Tongpim et al., 2009) ${ }^{10}$. Mortality and Relative Percent Survival were observed over 14 days. Noted that A. hydrophila suspension was a courtesy of Department of Microbiology, KhonKhaen University. RPS = (1mortality in treatment group/ mortality in control group) $\times 100$

\section{Analytical and Statistical Calculation}

The data were expressed as mean \pm standard deviation. Through SPSS commercial statistical package, data were analyzed using analysis of variance (ANOVA) for determining the significant differences over control values. The significance level was set at $p<0.05$.

\section{RESULTS}

\section{Growth Performance}

The effects of probiotic strain L. plantarum CR1T5 supplement on growth performance and feed efficiency in $P$. larnaudii were show in Table 1 and 2 . Fish received probiotic supplements at $10^{7}$, $10^{8}$ and $10^{9} \mathrm{cfu} \mathrm{g}^{-1}$ had significantly higher Specific growth rate (SGR) and lower feed conversion ratio(FCR) than fish that received the control diet at day 15 . While, fish fed $10^{6} \mathrm{cfu} \mathrm{g}{ }^{-1} \mathrm{~L}$. plantarum CR1T5 had significantly higher SGR and lower FCR at day 45.

\section{Immune Response}

\section{Lysozyme Activity}

The effects of $L$. plantarum CR1T5 dietary supplements in P. larnaudii are presented in Fig. 
Table 1. Effect of L. plantarum CR1T5 supplement on growth performance of $P$. larnaudii.

\begin{tabular}{|c|c|c|c|c|}
\hline \multirow[t]{2}{*}{ Diets } & \multicolumn{4}{|c|}{ SGR(days) } \\
\hline & 15 & 30 & 45 & 60 \\
\hline Control & $0.73 \pm 0.02^{\mathrm{a}}$ & $0.77 \pm 0.04^{a}$ & $0.76 \pm 0.02^{\mathrm{a}}$ & $0.80 \pm 0.02^{\mathrm{a}}$ \\
\hline L. plantarum $10^{6} \mathrm{cfu} \mathrm{g}^{-1}$ & $0.77 \pm 0.04^{\mathrm{ab}}$ & $0.82 \pm 0.02^{\mathrm{ab}}$ & $0.85 \pm 0.02^{b}$ & $0.87 \pm 0.02^{b}$ \\
\hline L. plantarum $10^{7} \mathrm{cfu} \mathrm{g}-1$ & $0.81 \pm 0.06^{b}$ & $0.87 \pm 0.02^{\mathrm{bc}}$ & $0.87 \pm 0.01^{\mathrm{b}}$ & $0.88 \pm 0.01^{b}$ \\
\hline L. plantarum $10^{8} \mathrm{cfu} \mathrm{g}^{-1}$ & $0.83 \pm 0.02^{b}$ & $0.88 \pm 0.03^{b c}$ & $0.91 \pm 0.03^{c}$ & $0.89 \pm 0.02^{b c}$ \\
\hline L. plantarum $10^{9} \mathrm{cfu}^{-1}$ & $0.83 \pm 0.02^{b}$ & $0.92 \pm 0.05^{c}$ & $0.95 \pm 0.02^{d}$ & $0.93 \pm 0.12^{c}$ \\
\hline
\end{tabular}

Data represent the mean $( \pm S . E$.$) ; The mean values in same column with different letters are significantly different (p<0.05)$

Table 2. Effect of $L$. plantarum CR1T5 supplement on feed efficiency of $P$. larnaudii.

\begin{tabular}{lcccc}
\hline Diets & \multicolumn{4}{c}{ FCR (days) } \\
\cline { 2 - 5 } & 15 & 30 & 45 & 60 \\
\hline Control & $2.59 \pm 0.06^{\mathrm{a}}$ & $2.45 \pm 0.13^{\mathrm{a}}$ & $2.50 \pm 0.08^{\mathrm{a}}$ & $2.35 \pm 0.08^{\mathrm{a}}$ \\
${\text { L. plantarum } 10^{6} \mathrm{cfu} \mathrm{g}^{-1}}^{2.47 \pm 0.15^{\mathrm{ab}}}$ & $2.28 \pm 0.05^{\mathrm{ab}}$ & $2.18 \pm 0.07^{\mathrm{b}}$ & $2.12 \pm 0.07^{\mathrm{b}}$ \\
L. plantarum $10^{7} \mathrm{cfu} \mathrm{g}^{-1}$ & $2.34 \pm 0.19^{\mathrm{b}}$ & $2.15 \pm 0.05^{\mathrm{bc}}$ & $2.17 \pm 0.04^{\mathrm{bc}}$ & $2.13 \pm 0.04^{\mathrm{b}}$ \\
L. plantarum $10^{8} \mathrm{cfu} \mathrm{g}^{-1}$ & $2.27 \pm 0.07^{\mathrm{b}}$ & $2.13 \pm 0.09^{\mathrm{bc}}$ & $2.05 \pm 0.08^{\mathrm{cd}}$ & $2.08 \pm 0.06^{\mathrm{bc}}$ \\
L. plantarum $10^{9} \mathrm{cfu} \mathrm{g}^{-1}$ & $2.26 \pm 0.06^{\mathrm{b}}$ & $2.02 \pm 0.13^{\mathrm{c}}$ & $1.94 \pm 0.04^{\mathrm{d}}$ & $2.00 \pm 0.04^{\mathrm{c}}$
\end{tabular}

Data represent the mean $( \pm$ S.E.); The mean values in same column with different letters are significantly different $(p<0.05)$

1a. The serum activities in fish fed $10^{8} \mathrm{cfu} \mathrm{g}^{-1}$ and $10^{9} \mathrm{cfu} \mathrm{g}^{-1}$ probiotic supplement had significantly $(p<0.05)$ increased when compared to the control diet both at day 45 and day 60 .

Respiratory Burst Activity

The results of dietary supplement to respiratory burst activity are shown in Fig. 1b. All supplement significantly improved respiratory burst activity $(p<0.05)$ at 30, 45 and 60 days.

Alternative Complement Pathway (ACH50 Activity)

The serum $\mathrm{ACH} 50$ activity in probiotics dietary supplement at $10^{8} \mathrm{cfu} \mathrm{g}^{-1}$ and $10^{9} \mathrm{cfu} \mathrm{g}^{-1}$ had significantly $(p<0.05)$ increased at 30,45 and 60 days. whereas the $\mathrm{ACH} 50$ activity in fish received probiotic diets at $10^{7} \mathrm{cfu} \mathrm{g}^{-1}$ and $10^{6} \mathrm{cfu} \mathrm{g}^{-1}$ were significantly different from the control group at 30 and 45 days. (Fig. 1c)

Challenge Test

Relative percent survival (RPS) of $P$. larnaudii is shown in Fig. 2. All fish received probiotic dietary supplement displayed a significant different RPS post-challenge with $A$. hydrophila.

\section{DISCUSSION}

Lactobacillus plantarum is a lactic acid bacterium which has been used as probiotic in aquaculture to improve growth performance, increase survival rate, resistance against pathogen and enhance immune system in aquatic animals. The results in this study indicated that $L$. plantarum CR1T5 dietary supplements fed on $P$. larnaudii at $10^{7}, 10^{8}$ and $10^{9} \mathrm{cfu} \mathrm{g}^{-1}$ caused lower feed conversion rate and higher growth performance. L. plantarum CR1T5 diet supplements may promote the growth performance and feed efficiency. The improvement of nutrient utilization in fish has resulted from the ability to compete with pathogens for essential nutrients, adhesion for binding to the wall of the digestive tract of fish and the ability of cells to produce metabolites and enzymes (Pandiyan et. al., 2013) ${ }^{11}$. Pathogens that cannot adhere and colonize in digestive tract are released by excretion. As a result, microorganisms maintain balance in digestive tract which lead to better performances of growth and feed efficiency of fish. In a previous study, Nile tilapia (Oreochromis niloticus) fed with $1 \%$ probiotic mixture of 

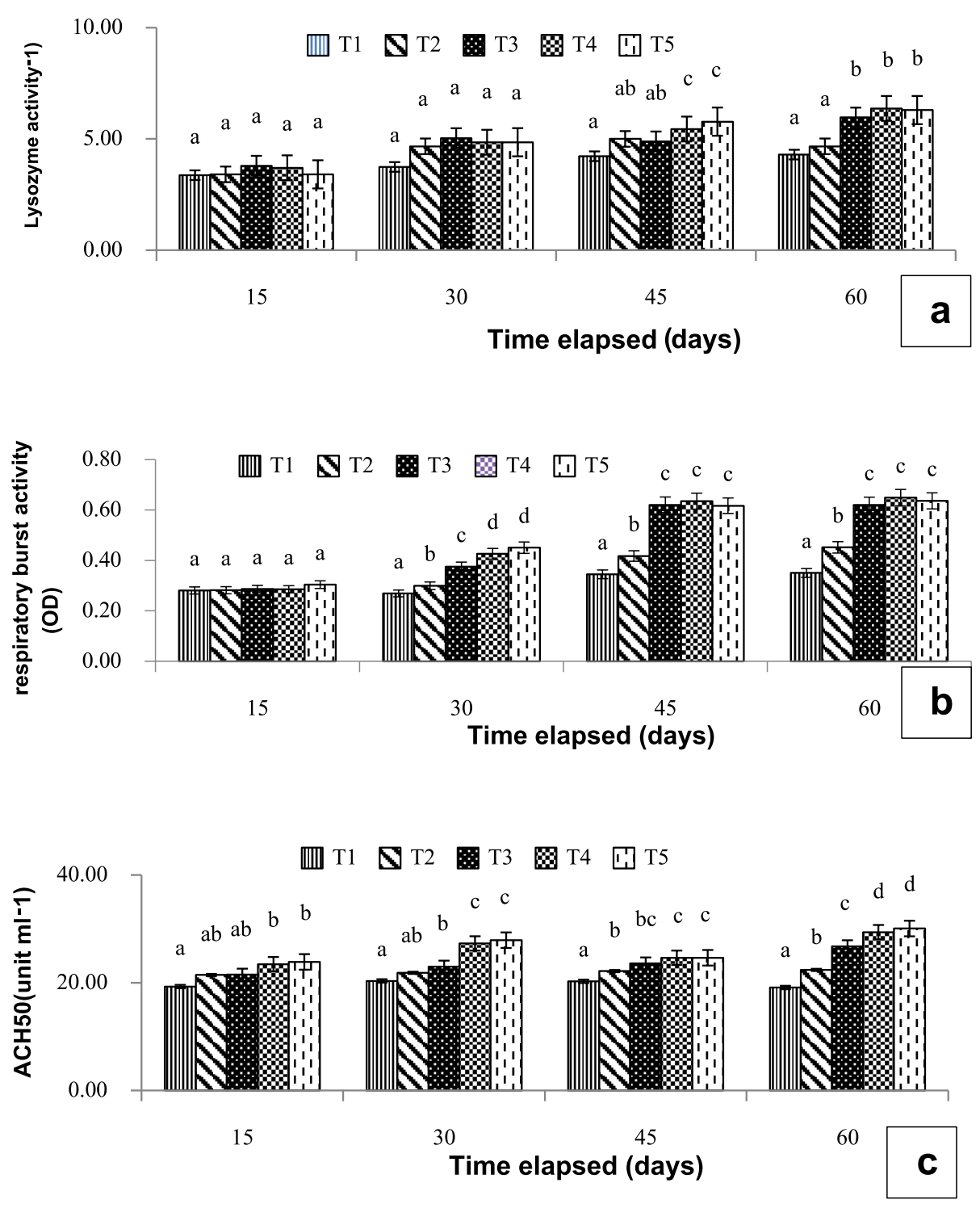

Fig. 1. Lysozyme activity;(a), respiratory burst activity; (b) and alternative complement activity; (c) of P. larnaudii fed with $L$. plantarum $\mathrm{CR} 1 \mathrm{~T} 5$ at $0(\mathrm{~T} 1), 10^{6}(\mathrm{~T} 2), 10^{7}(\mathrm{~T} 3), 10^{8}(\mathrm{~T} 4) 10^{9}(\mathrm{~T} 5) \mathrm{cfug}^{-1}$. Data represent the mean ( $\pm \mathrm{S}$. E.). Different letters indicate a significant difference $(P<0.05)$ between values when compared by Duncan's multiple range test.

Lactobacillus acidophilus and Streptococcus faecium showed better growth and feed utilization than fish that fed control diet. (Lara-Flores et al., 2003)..$^{12}$ Grouper (Epinephelus-coioides) fed with L. plantarum dietary supplement especially at $10^{8} \mathrm{cfu} \mathrm{kg}^{-1}$ for 4 weeks had a significantly increased percentage of weight gain, and feed efficiency (Son et. al. 2009). ${ }^{13}$ Dietary administration of $L$. plantarum VSG3 at $0,10^{6}, 10^{8}$ and $10^{10} \mathrm{cfu} \mathrm{g}^{-1}$ had significant effects on the specific growth rate and feed utilization efficiency of Labiorohita (Giri et. al. 2013) $)^{14}$.

Either monospecies or multiple speciesof probiotics, including Lactobacillus, Lactococcus, Enterococcus, Carnobacterium, Bacillus, Enterobacter, Pseudomonas, Clostridium, and Saccharomyces species, were used in aquaculture practices for improving growth and disease resistance (Nayak, 2010) ${ }^{15}$. Fish defenses against pathogens via modulation of immune system which 


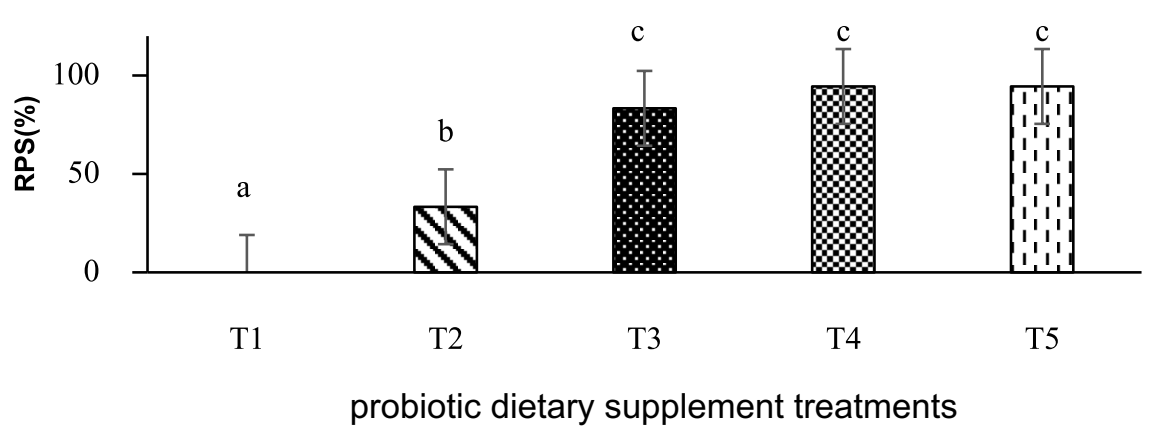

Fig. 2. Relative percent survival of $P$. larnaudii fed with $L$. plantarum CR1T5 at $0(T 1), 10^{6}(\mathrm{~T} 2), 10^{7}(\mathrm{~T} 3), 10^{8}(\mathrm{~T} 4) 10^{9}(\mathrm{~T} 5)$ $\mathrm{cfu} \mathrm{g}^{-1}$. Data represent the mean $( \pm$ S.E.). Different letters indicate a significant difference $(P<0.05)$ between values when compared by Duncan's multiple range test.

consists of physical barriers, humoral and cellular components. Innate humoral immunity includes lysozyme, complement, transferrin, lectins and antiproteases while innate cellular immunity is comprised of phagocytes, including macrophage and neutrophils. These components can be used as parameter to determine status of innate immune response of fish (Magnadottir, 2006) ${ }^{16}$. Lysozyme is an important enzyme in non-specific immune, which protects fish from invading pathogenic bacteria by splitting the $\lambda$-1-4- linkages between $\mathrm{N}$-acetylmuramic acid and $\mathrm{N}$-acetylglucosamine in the bacterial cell walls peptidoglycan (Saurabh and Sahoo, 2008) ${ }^{17}$. Lysozyme itself is known to attack gram positive bacteria directly while lysozyme in conjugation with complement can attack gram negative bacteria(Paulsen et al., 2001) ${ }^{18}$. Complement may eliminate pathogens via cell membranelysis and activation of non-specific mediators in inflammation process. Complement system has facilitate schemotoxis, opsonisation and pathogen destruction (Holland and Lambris, 2002) $)^{19}$. Innate cellular components include various types of white blood cells, e.g. macrophages and neutrophils. These white blood cells directly eliminate bacterial cells by phagocytosis. Macrophages and neutrophils can also induce respiratory burst by producing reactive oxygen species compounds. The superoxide anion $\left(\mathrm{O}_{2}^{-}\right)$initiates the respiratory burst and yields antimicrobial compounds, including hydrogen peroxide $\left(\mathrm{H}_{2} \mathrm{O}_{2}\right)$, hydroxyl radical $\left(\mathrm{OH}^{-}\right)$, hypochlorous acid $\left(\mathrm{OCl}^{-}\right)$and peroxynitrite (ONOO-) (Gomez and Balcazar, 2008) . $^{20}$.

Lactobacillus is a lactic acid bacterium which is used as a biological control agent in aquaculture practices (Balcazar et al., 2006) ${ }^{21}$. Lactobacillus ferment carbohydrates mainly into lactate and acetate. It can also produce bacteriocin which inhibits the growth of Grampositive and Gram-negative bacteria (Lash et al., 2005) ${ }^{22}$. Lactobacillus is beneficial flora of gastrointestinal tract of fish (Galindo, 2004). ${ }^{23}$ Nowadays, Lactobacillus spp. were used as probiotic dietary supplements to improve innate immune and disease resistance in various fish (Genget al., 2012) ${ }^{24}$. The use of Lactobacillus in many reports showed positive results in fish. The results from this study indicated that dietary $L$. plantarum CR1T5 supplements at $10^{8}$ and $10^{9} \mathrm{cfu}$ $\mathrm{g}^{-1}$ were the optimum concentration which led to increase of immune parameters at different time of feeding. The immune parameter in fish has been reported to increase after feeding with Lactobacillus sp. dietary supplement and in response to pathogens. In a previous study, lysozyme activity and complement activity in rainbow trout (Oncorhynchus mykiss) were greater in fish fed $10^{11} \mathrm{cfu} \mathrm{g}^{-1}$ of $L$. rhamnosus JCM 1136 (Panigrahi et al., 2004)25. The similar results reported by Abumourad et. al.(2013) ${ }^{26}$, that the diet containing L. plantarum at $10^{6} \mathrm{cfu}$ $\mathrm{g}^{-1}$ showed significantly improvement of growth rate, protection against Pseudomonas fluorescens in Oreochromis niloticus. In contrast, using $L$. plantarum dietary supplements on nursing of Macrobrachium roenbergii showed no significant differences in terms of growth, specific growth rate and survival rate (Sangpara and Doolginda-chabaporn, 2010) ${ }^{27}$. Dietary $L$. plantarum administration for 4 weeks revealed resistance to Streptococcus sp. and irido virus 
infection and had significantly increase the lysozyme activity, glutathione peroxidase (GPx) activity complement activity and respiratory burst activity in Epinephelus coioides (Son et.al., 2009) ${ }^{13}$. The study in kelp grouper (Epinephelus bruneus) fed with L.sakei BK19 at $10^{8}$ cells ${ }^{-1}$ supplementary diet for 2 weeks showed significantly enhancement of head kidney macrophage phagocytic and peroxidase activities, serum lysozyme activity, and total protein levels. The result of $L$. sakei BK19 enriched diet revealed the higher level of disease protection in streptococcus-infected kelp grouper (Harikrishnan et. al., 2010) ${ }^{28}$. Further more, Giri et al. $(2013)^{14}$ reported that the tropical fresh water fish, Labeorohita fed dietary administration of L. plantarum VSG3 at $0,10^{6}, 10^{8}, 10^{10} \mathrm{cfu} \mathrm{g}^{-1}$ had significantly increased the serum lysozyme and alternative complement pathway (ACP) activities, phagocytosis and respiratory burst activity after 30 and 60 days of post-feeding.

The challenge test revealed that all fish fed probiotic $L$. plantarum CR1T5 had significantly increased survival rate compared to the control. Carnevali et al. (2004) ${ }^{29}$ reported that L. plantarum (906) dietary supplement had significantly decreased larvae and fry mortality of sea bream (Sparus aurata). Rainbow trout (Onchorhynchus mykis) fed with L. plantarum CLFP 238 at $10^{7} \mathrm{cfu}$ $\mathrm{g}^{-1}$ for 30 days showed reduced mortality after challenged with Lactococ-cusgarvieae. (Vendrell

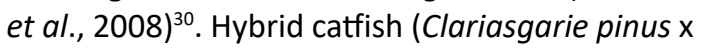
Clariasma-croceplalus) fed diet supplement with L. plantarum $\mathrm{C} 014$ at $10^{7} \mathrm{cfu} \mathrm{g}^{-1}$ had lysozyme activity increased. The fish challenged with $A$. hydrophila showed reduction of mortality rate after 45 days of feeding (Butprom et al., 2013) ${ }^{31}$. Labeorohita administerd with the diets containing of L. plantarum VSG3 at $10^{8}$ and $10^{10} \mathrm{cfu} \mathrm{g}^{-1}$ had significantly higher on disease resistance against Aeromonas hydrophila infection (Giri et al., $2013)^{14}$. Administration of L. rhamnosus at $10^{9}$ and $10^{12} \mathrm{cfu} \mathrm{g}^{-1}$ for 51 days increased the survival rate of rainbow trout after challenged with Aeromonas-salmonicida (Nikoskelainen et al., 2001) $)^{32}$. Therefore, using probiotic Lactobacillus spp. can increase disease resistance in fish. Probiotic dietary supplement in fish improved growth performance, immune parameter and pathogen resistance. However, the effects of probiotic bacteria on growth performance and immune parameter may be affected by feeding duration, the concentration of probiotic, the species of fish, environmental conditions and the quality and quantity of food dietary ingredients

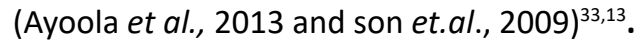

\section{CONCLUSIONS}

Dietary L. plantarum CR1T5 supplements at $10^{8}$ and $10^{9} \mathrm{cfu} \mathrm{g}^{-1}$ can improve the best growth performance and complement activity at 15 days post-feed while, probiotic diets at $10^{8} \mathrm{cfu}^{-1}$ stimulated lysozyme activity and respiratory burst activity at 45 and 30 days of feeding. Defending against infection in fish was found in fish all of group probiotic supplements.

\section{ACKNOWLEDGEMENTS}

This was partly supported by the Ministry of Science and Technology, Thailand for financial assistance. Thanks are also due to Department of Fisheries, Faculty of Agriculture, Department of Microbiology, Faculty of Science and Department of Clinical Microbiology, Faculty of Associated Medical Sciences, Khon Kaen University for facilities.

\section{CONFLICT OF INTERESTS}

The authors declare that there are no conflicts of interest.

\section{REFERENCES}

1 Rainboth, W. J. Fishes of the Cambodian Mekong. FAO (Food and agriculture organization of the United Nations), 1996, 265 p.

2 Brien, J, O, B., Crittenden, R.,Ouwehand, A. C. and Salminenc, S. Safety evaluation of probiotics. Trends in Food Science \& Technology, 1999; 10: 418-424.

3 Ringo, E. and Gatesoupe, F. J. Lactic acid bacteria in fish: a review. Aquaculture, 1998; 160: 177-203.

4 Verschuere, L., Rombaut.G., Sorgeloos, P. and Verstraete, W. Probiotic Bacteria as Biological Control Agents in Aquaculture. Microbiology and Molecular Biology Reviews, 2000; 16(4): 655-671.

5 Meidong, R., Doolgindachbaporn, S., sakai, K. and Tongpim, S. Isolation and selection of lactic acid bacteria from Thai indigenous fermented foods for use as probiotics in tilapia fish Oreochro-misniloticus. AACL Bioflux, 2017; 10(2): 455-463.

6 Stickney, R. R. Aquaculture: An Introductory Text, $2^{\text {nd }}$ Edition. Cambridge University Press, Cambridge, London, 2009; 304 p.

7 Obach, A., Quentel, C. and Laurencin, B. F. Effects of alpha-tocopherol and dietary oxidized fish oil on the immune response of sea bass (Dicentrarchuslabrax). 
Dis. Aquat. Organ, 1993; 13: 175-185.

8 Secombes, C. J. Isolation of salmoid macrophages and analysis of their killing activity.pp 137-155. In: Stolen, J.s., F.T.,Anderson, D.P. Roberson B.S., VAN WB, W INKEL $M$ (ed) Techniques in Fish Immunology, New Jersey: SOS Publication, 1990.

9 Yano, T. Assays of haemolytic complement activity. 1992, pp. 131-141.In: Stolen, J.S., Fletcher, T.C., Anderson, D.P., Kaattari, S.L. and Rowley, A.F. (Eds.): Techniques in Fish Immunology. Fair Haven, NJ: SOS Publications.

10 Tongpim, S, Meidong, R., Nontaso, N., and Doolgindachbaporn, S. Screening of lactic acid bacteria to be used as probiotics in Tilapia fish. The 3th International Conference on Fermentation Technology for Value Added Agricultural Products, Klangnanatham, Khon Kaen, 2009; pp. 55

11 Pandiyan, P., Balaraman, D., Thirunavuk-karasu, R., Gnana, E., George, J., Subaramaniyan, K., Manikkam, S. and Sadayappan, B. Probiotics in aquaculture.drug invention today, 2013; 5: 55-59

12 Lara-Flores, M., Olvera-Novoaa,M.A., Guzmבn-Mי ndezb, B.E.and Lqpez-Madridb, W. Use of the bacteria Streptococcus faeciumand Lactoba-cillus acidophilus and the yeastSaccharomyces cerevisiaeas growth promoters inNile tilapia (Oreochro-misniloticus). Aquaculture, 2003; 216: 193-201.

13 Son,V, M., Chang,C. C., Wu,M., Guu,Y. K., Chiu,C. H. and Cheng,W. Dietary administration of the probiotic, Lactoba-cillus plantarum, enhanced the growth, innate immune responses, and disease resistance of the grouper Epinephelus-coioides. Fish Shellfish Immunol, 2009; 26(5): 691-8.

14 Giri, S. S., Sukumaran,V.and Oviya, M. Potential probiotic Lactobacillus plantarum VSG3 improves the growth, immunity, and disease resistance of tropical freshwater fish, Labeorohita. Fish \& Shellfish Immunology, 2013; 34 : 660-666.

15 Nayak, S. K. Probiotics and immunity: a fish perspective. Fish Shellfish Immunol, 2010; 29(1) : 2-14

16 Magnadottir, B. Innate immunity of fish (overview). Fish Shellfish Immunol., 2006; 20(2) : 137-151.

17 Saurabh, S. and Sahoo, P. K. Lysozyme: An important defense molecule of fish innate immune system. Aquaculture Research, 2008; 39: 223-239.

18 Paulsen, S.M.,Engstad, R.E.,Robertsen, B. Enhanced lysozyme production in Atlantic salmon (Salmosalar L.) macrophages treated with yeast $\lambda$-glucan and bacterial lipopolysaccharide. Fish Shellfish Immunol, 2001; 11: 23-37.

19 Holland, M.C.H.and Lambris, J.D. The complement system in teleosts. Fish Shellfish Immunol, 2002; 12: 399-420.

20 Gomez, G. D. and Balcazar, J. Areview on the interactions between gut microbiota and innate Immunity of fish. FEMS Immunol Med Microbiol, 2008; 52: 145-154.

21 Balcazar, J.L., Blas,I.de., Ruiz-Zarzuela,I. Cunningham,D., Vendrell, D.and Muzquiz, J.L. The role of probiotics in aquaculture. Veterinary Microbiology, 2006; 114:173-186.
Lash, B.W., Mysliwiec, T.H.and Gourama,H. Detection and partial characterization of a broad-range bacteriocin produced by Lactobacillus plantarum (ATCC 8014). Food Microbiology, 2005; 22:199-204.

23 Galindo, A.B. Lactobacillus plantarum 44A as a live feed supplement for freshwater fish. Ph.D. Thesis, Wageningen University, Wageningen, The Netherlands, 2004; pp: 131.

24 Geng, X., Dong,X.H., Tan,B.P.,Yang,Q.H., Chi,S.Y., Liu,H.Y.and Liu, X.Q. Effects of dietary probiotic on the growth performance, non-specific immunity and disease resistance of cobia, Rachycentron-canadum. Aquaculture Nutrition, 2012; 18(1):46-55.

25 Panigrahi, A., Kiron,V., Kobayashi,T., Puangkaew,J., Satoh,S. and Sugita,H. Immuneresponses in rainbow trout On corhynchusmykiss induced by a potential probiotic bacteria Lactobacillus rhamnosus JCM 1136. Veterinary Immunology and Immunopathology, 2004; 102: 379-388.

26 Abumourad, M. K. I., Abbas, W. T., Awaad, E. S., Authman, M. M. N., El-Shafei, K., Sharaf, O. M. Evaluation of Lactobacillus plantarum as a probiotic in aquaculture: emphasis on growth performance and innate immunity. J. Appl. Sci. Res., 2013; 9: 572-582.

27 Sangpara, T. and Doolgindachabaporn, S. Nursing of Post Larval Giant Freshwater Prawn, Macrobrachiumrosenbergii with Food Pellet Mixed with Probiotic (Lactobacillus plantarum) at Vary Concentration Levels. RMUTTO Research journal, 2010; 3(2): 96-144

28 Harikrishnan, R., Balasundaram, C. and Heo, M. S. Lactobacillus sakei BK19 enriched diet enhances the immunity status and disease resistance to streptococcosis infection in kelp grouper, Epinephelusbruneus. Fish \& Shellfish Immunology, 2010; 29: 1037-1043.

29 Carnevali, O., Zamponi, M.C., Sulpizio, R., Rollo, A., Nardi, M., Orpianesi, C., Silvi, S.,Caggiano, M., Polzonetti, A.M. andCresci, A. Administration of probiotic strain to improve sea bream wellness during development. Aquac. Int., 2004; 12: 377-386.

30 Vendrell, D., Balcבzar,J.L., Blas,I.de., Ruiz-Zarzuela,I., Girones, O.and Mrzquiz, J.L. Protection of rainbow trout (Oncorhy-nchusmykiss) from lactococcosis by probiotic bacteria. Comp. Immunol. Microbiol. Infec. Dis., 2008; 31:337-345.

31 Butprom, S., Phumkhachorn, P. and Rattanachaikunsopon, P. Effect of Lactobacillus plantarum C014 on immune response and disease resistance against Aeromona-shydrophila in Hybrid catfish.The scientific world journal, 2013 : 1-6.

32 Nikoskelainen, S., Salminen, S., Bylund, G. and Ouwehand, A. C. Characterization of the properties of human-and dairy-derived probiotics for prevention of infectious diseases in fish. Appl. Environ. Microbiol., 2001; 67: 2430-2435.

33 Ayoola, S. O., Ajani, E. K. and Fashae, O. F. Effect of Probiotics (Lactobacillus and Bifidobacterium) on Growth Performance and Hematological Profile of Clariasga-riepinusJuveniles. World Journal of Fish and Marine Sciences, 2013; 5(1): 01-08. 